\title{
Discourse «Decommunisation» In A Public Plane Of Contemporary Ukrainian Information Space
}

\author{
Hitrova Tetyana Ph.D. ${ }^{1, a^{*}}$, Tsvetayeva Elena Ph.D. ${ }^{2, b}$ \\ ${ }^{1}$ Ukraine, 69000, Zaporizhzhia, Zhukovskogo str., 70b \\ ${ }^{2}$ Ukraine, 49023, Dnepropetrovsk, Karuna str., 119/6 \\ ahittv@rambler.ru, 'lenatsw@mail.ru
}

\begin{abstract}
Keywords: decommunisation, discourse, content, contextualization, communicative strategies,
\end{abstract} media, publicistic discussion.

\begin{abstract}
The article examines the discourse of «decommunisation» in a public plane of the modern Ukrainian information space. Its rhetorical dominant is represented by the communication strategies of the supporters and opponents of the package of «historical» laws adopted by the Verkhovna Rada of Ukraine on April 9, 2015. The author of the article has reproduced the chronical development of discourse «decommunisation» within the national concept of «historical memory».

European practice of condemnation of communist crimes was analyzed; factual material representing the international dialogue discussion Ukrainian decommunisation process was involved.
\end{abstract}

Special attention is given to the issue of decommunisation of the media sector, it was emphasised on the controversial aspects of interpretation of legislation «purification» from the Soviet Communist symbols.

Functional explications of discourse «decommunisation» in the media were studied, in particular within the event content, social content of the problem, subject-content argumentation and contextualization in international, legal, moral and ethical plane, mythologizing the narrative.

On the basis of factual material the basic meaning of the public topics of the analyzed discourse flow was revealed, it was indicated on its dependence of the communication purpose of the speeches. Infographic representation of the component «decommunisation» in the media has been analyzed, including the frequency of use of official symbols and their substantive relevance. It was revealed that the information occasion and the intensity of publications within the discourse is caused not only by the event content, but also by the methodological source (Calendar of decommunisation), developed by the Ukrainian Institute of National Memory.

The reasoning patterns of the texts were analyzed and it was found that the strategy of «responsible contextualization» contributes to the formation of the constructive dialogue. It was indicated on the necessity of attraction of qualitative component of communicative media strategies, including the use of critical narratives.

The author has focused on the ambivalent influence of the discourse on the design of public opinion, the set of public representations which, depending on the purpose of communication, contributes to the formation conventional meanings, the effect of «normalization» and manipulation.

\section{Introduction.}

Intensive discussing of Ukrainian attempts of decommunisation today has acquired the status of a media trend and actually concerns both the mass media and public spaces in general.

The media have become a source of cultivation a substantial and perfomantive filling of the discourse «decommunisation», the scene of journalistic debates around the various versions of Soviet-Communist memory as a filter of stabilization / destabilization of the informational environment, «Get rid of Soviet symbols from public space means finally «let to go» that horrible past victims of the regime and not to remind them of it» - Said medialawyer Robert Golovenko in his own column in the» Ukrainian Truth «[1]. 


\section{Results and Discussion.}

Adopted on April 9, 2015 by the Verkhovna Rada of Ukraine «decommunisation package» of laws referred to the recognition of the state fighters for independence of Ukraine in the XX century, the opening of the archives of the Soviet repressive authorities, the condemnation of the communist and Nazi totalitarian regimes and perpetuate the victory over Nazism in World War II, has caused a wide public resonance in public space, became information-accumulative isolation factor of independent publicistic discourse of «decommunisation.»

Currently, the media discourse of «decommunisation» can be justified as a combination of positions and points of contemplation, that are substantiated by the functional implication of the concept of «memory» initiators, supporters and opponents of «historical laws». The initiators of decommunisation, rely primarily on the European experience: Germany, Czech Republic, Poland, Slovakia, Hungary, Lithuania, Latvia, Estonia, Georgia. From the perspective of media presentations of the initiators of discourse, «Memory» means everything that was repressed, suppressed or ignored in the past and therefore by its nature could not penetrate into the public spheres collectively acceptable. The journalistic texts of the «supporters» could be considered with the most saturated debate semiotic space, which actually are the broadcasters of mental code of «communist crimes» and represent the concept of formation the conventional meanings of the discourse - «responsible memory».

Informative strategies of opponents are characterized by excessive politicization and, as a result, the production of synthetic-image model that generates a series of manipulations, myths and fears, which are multiplied by the media not without the participation of Russian propagandists.

However, the formation and segmentation of the discourse «decommunisation» started much earlier, still at the time of the Soviet collapse and are associated with the information activities of the Ukrainian civil movements and organizations, including the People's Movement of Ukraine, Society «Memorial», Ukrainian Helsinki Union and others. Since obtaining the independence in 1991, the decommunisation process was implemented by removing the communist ideology from education and training. In media discussions he remained at the level of symptomatic press reflections. The discourse of «decommunisation» acquires the active development in the period of the presidency of Viktor Yushchenko, particularly during the discussion the Law «About the Holodomor of 1932-1933 in Ukraine», approved by the Parliament on the $28^{\text {th }}$ of November, 2006, and the recognition of OUN-UPA participants of the struggle for independence of Ukraine in the XX century, but once again is replaced by the opposition communication technologies of strategic information space. However, due to the need to protect and support of action participants on June 30, 2009, that destroyed the statue of Lenin, as a response to delay and obstruction of implementation of the Decree of the President "Elimination of monuments and memorials dedicated to the Holodomor and political repressions» [2], July 3, 2009, the decommunisation Committee was established in Kyiv, which included NGO «Lustration» All-Ukrainian Union «Freedom», the UNA-UNSO, VO «Trident» named after Stepan Bandera, Association of Researchers of famines in Ukraine, Society «Memorial» named after Vasyl Stus, the Organizing Committee of the International Court of Crimes of Communism, OUN, PA «Enlightenment», Union of Officers of Ukraine, MNCs, Student Brotherhood and other Ukrainian right-wing parties and civil society organizations, in general over 30. [3]

A characteristic feature of the discourse «decommunisation» of this period is its monopolization in the public space of Union «Freedom», which, of course, brought its political dividends. The intensive push for the national rehabilitation of the discourse «decommunisation» was the Revolution of dignity, and its accumulative important factor is the discourse- flow «Leninfall», which until today is presented in the event-driven segment of the analyzed discourse.

The purpose of the proposed research is the functional analysis of explication of the discourse «decommunisation» in modern media and its communicative purpose, basic communicative strategies, which are used by the supporters and the opponents of the package of «decommunisation laws». Moreover, the article author investigates the process of decommunisation of media sphere and public space in general. 
Now it is impossible to «deny the criminal nature of the communist regime 1917-1991in Ukraine» or justify it in the media, to heroize the Communist Party leaders and to create positive images of such heroes. Ukrainian media cannot be used to promote the communist and / or National Socialist (Nazi) totalitarian regimes and their symbols. All printed editions whose names contain the symbols of totalitarian regimes must be re-registered, the content of audiovisual media is limited, and the instructions for covering the events of 1917-1991 years in Ukraine are given. In the official statement the first deputy chairman of the State Committee of TV and Radio Bogdan Chervak condemned the previous activities of the Ukrainian media: «Instead of popularization of national culture, history, traditions, promotion of the consolidation of Ukrainian society, the unique opportunities of mass media were mostly used for unconcealed propaganda of «glorious» communism past and suspicious attractions of the defunct state, which now belong to the basic concepts of ideology of the Kremlin aggressor. As a result - the systematic imposition of inappropriate to the Ukrainian nation values and ideology, the distorted history that misinformed the significant portion of the citizens of Ukraine, especially in Crimea and Donbas, in the perception of their own homeland and awareness of national identity» [4] and emphasized on the further responsibility for dissemination of Bolshevik-imperial ideology. The process of changing the names of periodical issues and their renaming started quickly, particulary media market of Odessa region was one of the first that reacted («Soviet new» changed its name to «Time. People. Events», «Soviet Transnistria» to «Word of Transnistria»).

Some media owners responded rather critically to the president law. In particular, the newspaper «Komsomolskaya Pravda in Ukraine», which is belongs to «Ukrainian Media Holding» asked the Ministry of Justice to clarify whether the law of discommunisation applies the name of the edition. Editors assert that the Ministry has suggested a quote from the Charter of the Komsomol: «Komsomol - is an active assistant and the reserve of the Communist Party of the Soviet Union, which is leading and guiding force of Soviet society ...». The publication expresses the protest against the conclusions of the Ministry and points out that the norms of the law does not say that the names of law firms, newspapers and magazines cannot comprise the words associated with the Soviet era. «No answer how the existence of the name «Komsomolskaya Pravda in Ukraine» advocates or justifies the communist regime, taking into account that all materials of our publications do not contradict the current legislation «, - said the edition. Editorial board notes that the newspaper has become a brand name and the newspaper «Komsomolskaya Pravda» at its title comes out in the US and the Baltic States. Also, the publication is threatening that if they (the court) claim to its name, it can be interpreted in any way («Komsomolskaya Pravda in Ukraine». - № 103, 2015, 19 May).

The issues of limitations of freedom of speech in the Ukrainian media at the legislative level and led to international dialogue and caused the warnings from the Organization for Security and Cooperation in Europe, in particular as an opportunity to «suppress the political, critical and provocative statements in the media» [5].

The researchers Ukrainian Studies in many countries (Canada, USA, Poland, Germany, and United Kingdom) appealed to the President with an open letter where they posted the debatable issues of the laws, that contradict to international standards and contribute to geopolitical confrontation, promote the politicization of «historical memory»: (Open letter to scientists and experts on the so-called «anti-communist law») [6].

Thus the discourse «decommunisation» plane is represented with the rhetorical content and is appropriately represented by the communication strategies of supporters and opponents of «historical» laws. Communication appointment of the discourse in the media mostly takes place within the event content, subject-content argumentation and the contextualization in the international, legal, moral and ethical plane, and the mythologizing of the narrative.

The occurrent model of the discourse originates from the highlighting the process «Leninfall» and covers the whole news ticker (Ukrainian and international) about the «decommunisation». The study revealed that the informational occasion and the intensity of publications within the discourse is caused not only with the event content, but also a methodological source of "Calendar 
of Decommunisation» developed by the Ukrainian Institute of National Memory. It is a typical determinant,

a certain thematic scheme in which what and when should be renamed or removed is noted. Calendar displays the phased implementation of the basic rules of decommunisation laws: change of the names of juridical persons, the media, re-registration of trademarks, services, changing the toponymy, dismantle monuments and memorials.

Subject-substantive argumentation of «decommunisation», which is presented with the analytical and journalistic debate, directed to search the conventional meanings of «historical memory» and «historical justice» within the discourse in general and discussion / interpretation of the main theses of the laws in particular.

Search of strategies for «responsible contextualization» contributes to the formation of a constructive dialogue and reduces the risk of cognitive dissonance in the audience prone to «normalization». An example of qualitative argumentative structures of the discoursive texts is a weekly column of political analyst Vladimir Zolotarev in «Telekritika» - «Popular virology» (www.telekritika.ua/media-continent/authorcolumn/zoloto/). The author sets himself the goal to dismis from remaining authoritarian connotations of the Soviet newspeak in public communication, declaring at the outset the intention to return the original meanings, to release them from the «of consciousness viruses», as he metaphorically describes the erosion in terms of the public, including the mass media discourse. It should be mentioned that this particular aspect of «de-communization» is not reflected in the package of «historical» laws.

Publications / discussions about the legality of the Ukrainian «decommunisation» in international, legal, moral and ethical plane, as well as those that contain the proposals, recommendations, interpretation and professional evaluation of process can be attributed to the texts of discourse, which feature is the use of object- content argumentation. In particular, these are the publications in the special topics «The future of our past» and in the section «Politics of Historical Memory» in the magazine «Criticism». From the perspective genre variations within a definite kind of discourse, the journalistic review and the discussion of V. Vyatrovych «The decommunisation and the academic debate» is topical. [7]

The mythologizing of the discourse is implemented in ambivalent versions of the supporters and the critics of decommunisation, that exploit the mental filters «identity - values,» thus producing the effect of cognitive dissonance in the audience.

This strategy was substantiated quite aptly by A. Portnov: «It is interesting that in the heat of controversy the striking similarity often remains completely invisible, for example, «antiDonetsk» and «anti-Galitsk» rhetoric. The idea of the spoiled ideal is present in both narratives(dep ending on the ideological position - European or Orthodox), roughly simplified image of the virtual opposite group («residents of Galicia», «residents of Donbas») as possessing the «identity» or the «values» that their group allegedly aggressively enforces to the rest of the country, thus preventing it to «normalize» $[8]$.

The effect of «normalization» or «neutralization» is the generally widespread technology, directed to the omission and distortion of any versions able to put this «normality» in doubt, by means of deliberate misinformation, shift in emphasis, accusations, suggestions and stereotyping of fears (like the title «10 Years for propaganda») and so on. Nostalgia is the basic for the formation of the modern pro-Soviet / Russian-leaning narrative and the main communicative technologies of the opponents of «historical laws», the actual source of the cultivation of the oppositional discourse.

Among the common techniques which are used within the mythological models we come across such communicative scheme - do not argue with opponents but with yourself, imposing personal opinion and expression. The communicative effects, that were described above, can be found, in particular, in the publication of V. Pikhovshek "Is it fair that in Ukraine now instead of "decommunisation" they cram "banderization"?, which has caused a hefty splash of criticism from both supporters and opponents of the "historical laws".

The main objective of mythologizing the discourse is the creation of tensions around "laws on the discommunisation" themselves as facts, unscrewing the attention of their contents. A striking 
example of the embodiment of this task is to publish the numerous expert opinions, in particular, in an interview to "Voice of the Capital" political expert Alexander Zolotarev called the law on condemnation of Communist and Nazi totalitarian regimes "ideological hack" which" contains many questionable standards that cannot be a source of unification of the country, but even a greater discord and conflict ..." ". "What produces this law, it is - the monopoly on truth. Secondly, it is, in fact, the new dictatorial law. And thirdly, it is the law that unnecessarily criminalizes propaganda. For example, a red flag or the flag of victory ... "- outraged Alexander Zolotarev ("Voice of the capital". - 2015, September 4).

The shift of emphasis in the social aspect of the problem is a characteristic feature of communication strategies of their opponents.

The main topic of public intentions of critics aimed at the representation of discourse as a means of artificial "crosslinking" of the country, a tool of distraction of the public from dangerous trends in the socio-economic sphere. The semantic focus of these receptions reduced to the following abstracts: "Discommunisation is not the time. There are immediate problems that need solving - war, poverty, corruption, etc. "; "These laws divert public attention from economic and political reforms"; "The renaming of streets and population settlements need large funds, and people will have to change documents, paying for it from the their own pockets"; "Society does not accept the change of the names of streets and towns - especially the elderly people, for whom the Soviet era names are sacred"; "The law will complicate the scientific research of history of the Soviet period"; "The recognition of OUN-UPA fighters for independence will prevent the objective investigation of history, including the Polish-Ukrainian conflict in the first half of the XX century"; "These passed laws are prohibiting the communist ideology, limiting freedom of speech and freedom of opinion"; "These passed laws are canceling the holiday on May 9th and the celebration in honor of veterans of the Great Patriotic War".

Quite often an art becomes the object of manipulation of opponents, with the clear targeting of speeches to the supporters of the preservation of "Soviet monuments as piece of art", in particular, such practice occurs in the newspapers "Today", "News" and others. ("The destruction of statues of Lenin is no longer the vandalism but the implementation of the law". - «News". - 2015, 25 May). Although the law "On the condemnation of totalitarian regimes" provides an exception for works of art of the Soviet period. From the perspective of the editorial policy, the publication of such materials is another way to keep "their" readers and increase circulation using their emotions.

\section{Conclusion.}

Therefore, the discourse of "decommunisation" in a public plane of modern Ukrainian informational environment has ambivalent impact on the construction of public opinion. It was born, first of all, with the help of the lack of critical narratives from the official speaker, and therefore is an effective platform for the operation of the political order. The analysis of factual material, in particular its subject-content argumentation, yet outlines the perspective of the discourse as the source of the formation of the new conventional meanings of the national model "historical memory". Involvement of the argumentative structures of the text of discourse of the qualitative component of the communicative media strategies promotes the formation of the constructive dialogue and the concept of responsible memory. Prospects for the future research of discourse "decommunisation" could be the analysis of its semiotic space and cognitive-receptor characteristics research of counteraction - "counter discourse", the influence on the formation of modern informational policy in general. 


\section{References:}

[1]. Golovenko R. What is decommunisation public space and why it is needed / R. Golovenko [Electronic resource]. - Reference:

http://www.pravda.com.ua/columns/2015/08/21/7078532/?attempt=1. - Accessed: 28.08.2015

[2]. The Law of Ukraine "On the Holodomor of 1932-1933 in Ukraine" of 28 November 2006 r. № 376-V // Bulletin of the Verkhovna Rada of Ukraine. - 2006. - № 50. - Art. 504.

[3]. Ukrainian Institute of National Memory: official site [Electronic resource]. - Reference: http://www.memory.gov.ua/page/dekomunizatsiya-0

[4]. State Committee of TV and Radio urges the media to bring their activities into compliance with the law on discommunization [Electronic resource]. - Reference: http://www.telekritika.ua/pravo/2015-05-18/107179

[5]. OSCE: discommunization in Ukraine will restrict the freedom of speech in the media [Electronic resource]. - Reference: http://tyzhden.ua/News/136679.

[6]. Open letter of the scientists and the experts in Ukrainian Studies concerning the so-called "decommunisation law" [Electronic resource]. - Reference:

http://krytyka.com/ua/articles/vidkrytyy-lyst-naukovtsiv-ta-ekspertiv-ukrayinoznavtsivshchodo-tak-zvanoho\#sthash.nwXoLFJH.dpuf

[7]. Vyatrovych V. Discommunization and academic debate / V. Vyatrovych [Electronic resource]. - Reference:

http://krytyka.com/ua/solutions/opinions/dekomunizatsiya-i-akademichna-dyskusiya

[8]. Portnov A. About discommunization, identity and historical laws somewhat differently / A. Portnov [Electronic resource]. - Reference: http://krytyka.com/ua/solutions/opinions/prodekomunizatsiyu-identychnist-ta-istorychni-zakony-deshcho-inakshe\#sthash.rWOppQZF.dpuf 